Zbigniew Przygodzki ${ }^{*}$ Jakub Zasina ${ }^{* *}$

ROZDZIA IX

\title{
Kreowanie atrakcyjnych przestrzeni w miejscu pracy na rzecz wzmocnienia efektywności kapitału ludzkiego
}

\section{Wstęp}

Kapitał ludzki ma tendencje do koncentracji, co wynika z poszukiwania odpowiednich warunków do lokalizacji. Podobnie, jak w przypadku przedsiębiorstw, czynniki decydujące o lokalizacji kapitału ludzkiego w przestrzeni są zróżnicowane i często wzajemnie uwarunkowane. Jednym z podstawowych czynników determinujących atrakcyjność tej lokalizacji jest specyfika miejsca, w rozumieniu jego właściwości fizycznych, estetycznych, społecznych, komunikacyjnych ${ }^{1}$. Elementy te determinują tworzenie środowisk kreatywnych, które wzmacniają w kapitale ludzkim zdolności twórcze i potencjał intelektualny. Kapitał ludzki wymaga ukierunkowanych inwestycji oraz warunków determinujących jego właściwości jako czynnika rozwoju². Jedną z ważnych jego cech jest kreatywność - warunek niezbędny z punktu widzenia zdolności do tworzenia innowacji zarówno w wymiarze jednostki, jak i regionu ${ }^{3}$. Rodzi się zatem pyta-

* Adiunkt, Katedra Gospodarki Regionalnej i Środowiska, Wydział Ekonomiczno-Socjologiczny, Uniwersytet Łódzki. E-mail: zbycho@uni.lodz.pl

** Doktorant, Katedra Gospodarki Regionalnej i Środowiska, Wydział Ekonomiczno-Socjologiczny, Uniwersytet Łódzki. E-mail: j.zasina@uni.lodz.pl

${ }^{1}$ Szerzej na ten temat w artykule Z. Przygodzkiego pt. Audyt przestrzeni publicznych jako narzędzie monitorowania i kreowania atrakcyjnych przestrzeni dla rozwoju kapitału ludzkiego.

${ }^{2}$ Regionalny wymiar polityki rozwoju kapitału ludzkiego. Przykład Włoch, Wielkiej Brytanii, Niemiec i Polski, Z. Przygodzki (red.), Wydawnictwo Difin, Warszawa 2013.

${ }^{3}$ Zdolności innowacyjne, jak pisze A. Nowakowska w odniesieniu do regionów, są zróżnicowane i można je najogólniej podzielić na czynne i bierne. Można wyróżnić regiony: (1) zdolne do generowania i absorpcji innowacji, (2) zdolne do generowania innowacji (np. w jednostkach badawczo-rozwojowych), ale nie posiadające zdolności do ich absorpcji i adaptacji do gospodarki; (3) niezdolne do generowania innowacji, ale zdolne do ich absorpcji z zewnątrz i dyfuzji w środowisku regionalnym; (4) niezdolne ani do jednego, ani do drugiego - brak zdolności innowacyj- 
nie, w jaki sposób można pobudzać i zwiększać zdolności kreatywne kapitału ludzkiego? Odpowiedzi jest wiele, natomiast celem zrealizowanych badań była identyfikacja wpływu przestrzeni otaczającej człowieka w miejscu pracy, na jego zdolności kreatywne. Innymi słowy, celem było zdiagnozowanie poziomu dopasowania warunków przestrzeni pracy, do potrzeb wykorzystującego tę przestrzeń kapitału ludzkiego.

\section{Metodyka badań oceny atrakcyjności przestrzeni pracy przez pracownika naukowego}

Przystępując do realizacji badań, na wstępie zdefiniowano przedmiot, który bezpośrednio wynikał z celu pracy. Zrealizowano badanie, dotyczące bezpośredniego otoczenia pracy ludzi, zaangażowanych w tworzenie zasobów wiedzy zaawansowanej i innowacyjnej, stanowiących element i jednocześnie wspierających tworzenie klasy kreatywnej ${ }^{4}$. Analizę ograniczono zatem do oceny przestrzeni pracy środowisk kreatywnych. Podmiotem badania w tym przypadku byli pracownicy naukowi celowo wybranej jednostki Uniwersytetu Łódzkiego Wydziału Ekonomiczno-Socjologicznego (WE-S). Warunki miejsca pracy pracownika naukowego, bezpośrednio oddziałują na jego kreatywność i w konsekwencji osiagane wyniki. Specyfika tej pracy wskazuje na wiele cech wspólnych z tzw. wolnymi zawodami. Pracownik, mimo podległego stosunku pracy, najczęściej sam decyduje kiedy, z jaką intensywnościa, w jakim zakresie prowadzi prace badawcze. Jeśli nie jest zdeterminowany infrastrukturą badawczą zlokalizowaną w konkretnym miejscu (np. laboratoryjną, oprogramowaniem komputerowym), sam wybiera najdogodniejsze dla siebie miejsce pracy. Wybiera otoczenie, które pobudza kreatywność, pozwala myśleć i koncentrować uwagę, słowem - sprzyja efektywnej pracy. Powstaje zatem pytanie: czy lub jak często pomieszczenia wydziału, jako miejsca pracy dedykowane pracownikowi naukowemu, są jego miejscem pracy twórczej? Stąd cel badania sformułowano w sposób następujący: ocena wpływu oraz identyfikacja roli jakości przestrzeni otaczającej człowieka w pracy, na poziom jego aktywności i zdolności kreatywnych. Badaniu poddano pracowników naukowych WE-S, których praca naukowa nie jest najczęściej zależna od infrastruktury obecnej na wydziale. Pozwoliło to zatem pominąc kwestię przymusu związanego z wyborem przestrzeni pracy. Badaniu poddano całą populację - wszystkich 397 pracowników naukowych

nych. A. Nowakowska, Regionalny wymiar procesów innowacji, Wydawnictwo Uniwersytetu Łódzkiego, Łódź 2011, s. 41.

${ }^{4}$ Nowakowska A., Przygodzki Z., Sokołowicz M., Region w gospodarce opartej na wiedzy. Kapitat ludzki, innowacje, korporacje transnarodowe, Wydawnictwo Difin, Warszawa 2011, s. 18-19. 
wydziału, z czego 82 osoby (20,7\%) odpowiedziały na pytania przedstawione w kwestionariuszu ankietowym ${ }^{5}$.

Wyzwaniem drugorzędnym, choć także istotnym zarówno z perspektywy aplikacyjnej, jak i poprawności prowadzonej analizy oraz wyników pracy, było przygotowanie narzędzia oceny przestrzeni pracy. Konceptualizacja narzędzia badawczego ma charakter autorski, natomiast inspiracją $\mathrm{w}$ tym zakresie były dwa badania, zrealizowane na rzecz sektora prywatnego. Pierwsze dotyczyło instytucji sektora prywatnego, która znajdowała się na etapie budowy obiektu biurowego (Park Biznesu Teofilów) i zamierzała świadomie ukształtować przestrzeń, w założeniu determinującą efektywność i kreatywność pracy zespołowej ${ }^{6}$. Drugi przypadek dotyczył także instytucji sektora prywatnego (Centrum Biznesowe Kopcińskiego HammerMed), która posiadała już zorganizowaną, użytkowaną przestrzeń biurową, urządzoną pod kątem determinowania pracownika do efektywnej i kreatywnej pracy biurowej. W odróżnieniu od wyżej wskazanych przykładów, badania zrealizowane na Wydziale Ekonomiczno-Socjologicznym UŁ dotyczyły przestrzeni, która na etapie budowy i urządzania, nie była celowo kształtowana pod kątem determinowania rozwoju kapitału kreatywnego. Kolejne adaptacje budynków, przebudowy i remonty dokonywane były bez zaangażowania specjalistycznej wiedzy, badań preferencji i potrzeb pracowników naukowych.

Wydział Ekonomiczno-Socjologiczny - został utworzony w roku 1965 w wyniku połączenia struktur akademickich działających wcześniej na terenie Łodzi. Jednostka ta kształci obecnie w skali roku ponad 10000 studentów, co stanowi ponad jedną czwartą wszystkich adeptów Uniwersytetu Łódzkiego, a także zatrudnia blisko 397 pracowników naukowych ${ }^{7}$. Teren użytkowany przez wydział zajmuje powierzchnię niemal 2 ha i zlokalizowany jest w kwartale ulic Rewolucji 1905 r. - Polskiej Organizacji Wojskowej (POW) - S. Jaracza J. Kilińskiego. Oznacza to, że budynki wchodzące w skład wydziału umiejscowione są w północno-wschodniej części historycznego śródmieścia Łodzi. Otacza je przede wszystkim zabytkowa substancja mieszkaniowa z końca XIX wie$\mathrm{ku}$, jednak one same stanowią przykład nowoczesnej zabudowy. Charakter tych obiektów wynika nie tylko z okresów, w jakich poszczególne z nich wznoszono - począwszy od roku 1938 - ale również z przeprowadzonych w ciągu ostatnich dwóch dekad intensywnych prac modernizacyjnych. Pracownicy naukowi i studenci korzystają przede wszystkim z siedmiu budynków - do rozróżnienia któ-

${ }^{5}$ Według stanu zatrudnienia na Wydziale Ekonomiczno-Socjologicznym UŁ na 13.04.2012. Badania zrealizowane zostały przez Z. Przygodzkiego, J. Zasinę i A. Szewczyk w okresie 02-05.2012, w ramach projektu badawczego pt. Polityka i narzędzia kreowania kapitału ludzkiego w regionie, sfinansowanego ze środków na naukę w latach 2010-2013, nr N N114 183938.

${ }_{6}$ Akademia wymarzonego biura: Raport $\mathrm{z}$ badań fokusowych oraz Opracowanie wyników ankiety internetowej, Park Biznesu Teofilów, SKN LEADERS, SKN SPATIUM, Łódź 2011.

${ }^{7}$ Według stanu zatrudnienia na Wydziale Ekonomiczno-Socjologicznym UŁ na 13.04.2012. 
rych wykorzystuje się litery A, B, C, D, E, F oraz T (rysunek 1). Wydział otwarty jest w godzinach 07:00-21:00 (z wyjątkiem przerw semestralnych i wakacji). Choć poszczególne części wydziału powstawały oddzielnie, połączone są dziś korytarzami, co umożliwia poruszanie się między nimi bez wychodzenia na zewnątrz. Niestety jednak konsekwencją tego trybu budowania wydziału, czego nie zmieniły również kolejne jego remonty, jest brak wyraźnego miejsca centralnego. Jak pisze Ch. Alexander ,Zespół budynków bez centrum jest jak człowiek bez głowy"8. Najstarszymi obiektami są budynki A, B, C oraz D, a najkrócej użytkowanymi przez wydział są E i F, w których w 2010 roku ulokowano Centrum Informatyczno-Ekonometryczne. We wnętrzach większości z budynków WE-S znajdują się biura pracowników naukowych, pomieszczenia dydaktyczne i biura obsługi administracyjnej. Wyjątek stanowi budynek B, w którym nie prowadzi się zajęć dydaktycznych dla studentów.

\section{Rysunek 1. Budynki wchodzące w skład Wydziału Ekonomiczno-Socjologicznego UŁ} Uniwersytetu Łódzkiego wraz z oznaczeniami literowymi.

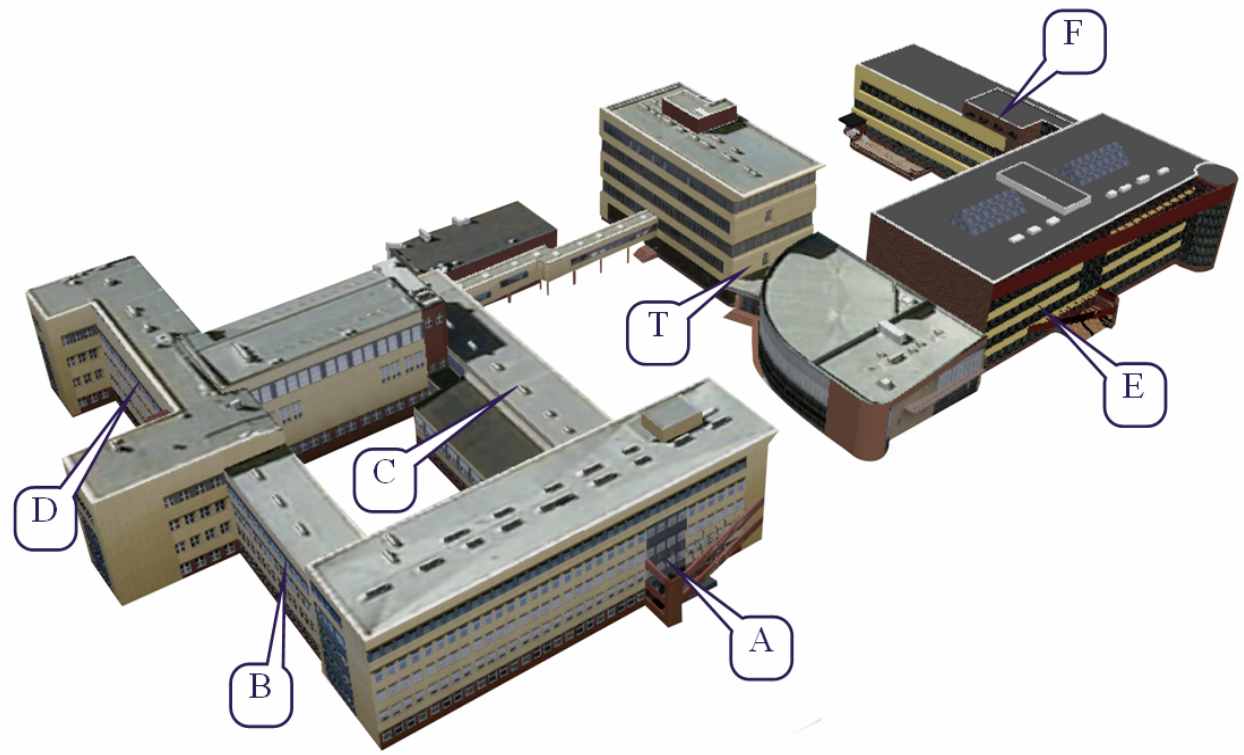

Źródło: opracowanie własne na podstawie modeli trójwymiarowych stworzonych przez Agnieszkę Czerwińską (budynki E i F) oraz Arkadiusza Pawłowskiego (A, B, C, D i T).

${ }^{8}$ Ch. Alexander, Język Wzorców. Miasta, budynki, konstrukcja, Gdańskie Wydawnictwo Psychologiczne, Sopot 2008, s. 492. 
Bazując na dobrych przykładach oraz wiedzy z zakresu literatury przedmiotu przygotowano narzędzie badawcze w postaci kwestionariusza ankietowego, który następnie rozesłano badanym pocztą elektroniczną ${ }^{9}$. Kwestionariusz składał się z 48 pytań, które zostały ułożone w czterech kategoriach:

- przestrzeń dla budowania relacji międzyludzkich, kapitału społecznego;

- estetyka;

- kształt budynków, rozwiązania techniczne, organizacja przestrzeni biurowej;

- organizacja pracy Wydziału.

Dla każdej kategorii określono miary szczegółowe w postaci wskaźników z przypisaną skalą Likerta, sześć pytań miało zaprogramowaną odpowiedź $\mathrm{w}$ postaci kafeterii i w pięciu przypadkach zaplanowano formułę pytania otwartego. Badania zrealizowano w okresie jednego miesiąca - w październiku 2012 roku, co było istotne z punktu widzenia zapewnienia pełnej bieżącej percepcji przestrzeni wydziału przez pracowników naukowych oraz jej rzeczywistego wpływu na jakość pracy. W grupie badanych najwięcej było pracowników naukowych ze stopniem doktora $(52,44 \%)$, następnie magistra $(31,71 \%)$ oraz doktora habilitowanego lub profesora $(15,85 \%)$. Nieznaczną nadreprezentację, w stosunku do rozkładu populacji generalnej wśród uczestników badania, stanowiły kobiety $(62,20 \%)$.

\section{Funkcje i percepcja przestrzeni w pracy naukowca}

Jeden z ważniejszych wniosków, który nasuwa się po analizie danych, dotyczy czasu, jaki pracownicy naukowi poświęcają pracy badawczej, przebywając na terenie wydziału. Średnio, zaledwie $18,5 \%$ tego czasu przeznacza się na pracę naukową. Zdecydowanie większość czasu pochłania respondentom działalność dydaktyczna $-56 \%$, natomiast ok. $20 \%$ czasu przeznaczają na działalność administracyjną. Relatywnie nieco więcej czasu na problemy związane z nauką poświęcają mężczyźni - 25,4\%, natomiast kobiety 17,5\%. Kobiety jednocześnie znacznie częściej niż mężczyźni realizują zadania administracyjne (odpowiednio $23,1 \%$ i 16,6\% czasu obecności na wydziale).

9 J. Gehl, Życie między budynkami. Użytkowanie przestrzeni publicznych, Wydawnictwo RAM, Kraków 2009; Ch. Alexander, Język Wzorców. Miasta, budynki, konstrukcja, Gdańskie Wydawnictwo Psychologiczne, Sopot 2008, E. Neufert, Podręczniki projektowania architektoniczno-budowlanego, Wydawnictwo Arkady, Warszawa 2008. 
Rysunek 2. Średnia ilość czasu poświęcanego na jeden z trzech filarów aktywności zawodowej pracowników naukowych podczas obecności na WE-S UŁ

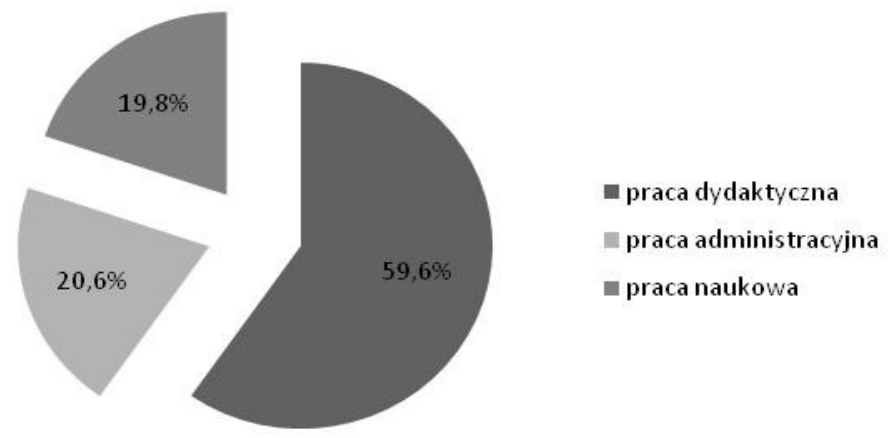

Źródło: opracowanie własne na podstawie badań

Zdecydowana większość badanych stwierdza, że lubi swoje otoczenie pracy. $70,7 \%$ wskazuje, że chętnie pracuje w swoim pokoju-biurze. Respondenci pozytywnie oceniają zarówno stan techniczny wykorzystywanych przez siebie pomieszczeń $(70,7 \%$ wskazuje poziom dobry i bardzo dobry, nikt nie wskazuje oceny złej), jak również ich estetykę i komfort użytkowania przestrzeni $(73,1 \%$ wskazuje poziom dobry i bardzo dobry - porównując do innych uczelni w kraju, nieco gorsze oceny formułowane są $\mathrm{w}$ porównaniu do uczelni za granica, $\mathrm{w}$ odniesieniu do których wynik ten kształtuje się na poziomie 41,5\%).

Zbliżony charakter opinii ma miejsce $\mathrm{w}$ przypadku oceny spójności estetycznej budynków wydziału, gdyż w tym kontekście ponad $61 \%$ badanych pozytywnie interpretuje tę przestrzeń (oceny dobre - 47,6\% i bardzo dobre - 13,5\%). Dodatkowo przyjmując założenie, że oceny dotyczące estetyki dokonywane są $\mathrm{w}$ dużej mierze na podstawie porównań $\mathrm{z}$ innymi, znanymi przez respondenta miejscami, poproszono ankietowanych o powtórną ocenę wrażeń estetycznych z uwzględnieniem kontekstu krajowego i międzynarodowego. Okazało się, że odsetek osób pozytywnie oceniających estetykę wydziału wzrasta do 70,8\%, gdy porównuje się ją z infrastrukturą innych polskich uczelni (oceny dobre - 53,7\% i bardzo dobre - 17,1\%). Natomiast na tle uczelni zagranicznych ankietowani oceniają WE-S UŁ na poziomie „przeciętnym” (26,8\% wskazań), jednak i tak większa część respondentów uważa, że wypada on w tym porównaniu "dobrze" $(24,4 \%)$ lub „bardzo dobrze” (17,1\%) niż „dostatecznie” (13,4\%) czy „źle” $(9,8 \%)$.

Obcując z miejscem, możliwe jest scharakteryzowanie go z wykorzystaniem odpowiednich przymiotników. Kolejnym etapem badania była więc chęć pozna- 
nia cech, jakimi pracownicy są w stanie określić zarówno wygląd zewnętrzny budynków wydziału, jak i ich wnętrza. Do dyspozycji badanych oddano osiemnastoelementową kafeterię odpowiedzi. Najwięcej spośród ankietowanych uważa wygląd zewnętrzny obiektów za: „uporządkowany” (52,4\%), „nowoczesny” $(43,9 \%)$ oraz „funkcjonalny” $(35,4 \%)$. Nie można natomiast powiedzieć o nim jako o „wrogim”, „odstraszającym” czy „klaustrofobicznym”, gdyż nikt nie zdecydował się na zaznaczenie tych odpowiedzi. Podobna sytuacja miała miejsce w przypadku przymiotnika, ,intrygujący”. Jakich cech w związku z tym użyto do scharakteryzowania wnętrz wydziału? Dominowały trzy odpowiedzi: ,uporządkowane” (43,9\%), „bez charakteru” (37,8\%) i „tradycyjne” (36,6\%). Wnętrza nie są ani ,intrygujące”, ani „dostojne”, ani „wrogie”, ani „odstraszające” (98,8\% ankietowanych nie użyło tych odpowiedzi). W kontekście uzyskanych wyników warto zauważyć, że na dodatkowe pytanie „Czy preferowaliby Państwo, aby wnętrze każdego z budynków wydziału miało swój unikalny i niepowtarzalny charakter - stylizację?” aż $26,8 \%$ pracowników odpowiedziało „,raczej tak", a $25,6 \%$ z nich wybrało odpowiedź ,tak”.

Podsumowując można zauważyć, iż respondenci zdecydowanie traktują wydział jako przestrzeń biurowa, dedykowaną pracy odtwórczej i technicznej. Przestrzeń ta nie stanowi dla badanych środowiska inspirującego do działania, nie pobudza kreatywności. Jest to głównie przestrzeń o właściwościach funkcjonalnych (tak określa ją 28,1\% badanych), zdefiniowana w tradycyjny $(36,6 \%$ wskazań), dość nudny sposób (19,5\% wskazań). Nieliczni respondenci określali wydział jako miejsce ciekawe $(6,1 \%)$, a niezwykle rzadko przypisywali temu miejscu takie cechy jak oryginalność, czy innowacyjność (3,6\%). Znaczna część ankietowanych określiła wydział miejscem bez charakteru (37,8\%). 42,3\% badanych stwierdza jednocześnie, że miejsce to (w szczególności ich pokój) nie sprzyja pracy naukowej, a w grupie twierdzących przeciwnie, jedynie $23,6 \%$ czasu przebywania na wydziale przeznacza się na pracę naukową. Respondenci jako podstawowe wyttumaczenie tego stanu rzeczy podają brak separacji czesści biurowej pomieszczeń od części dydaktycznej. Integracja tych dwóch funkcji skutecznie obniża zdolność do koncentracji, głównie na skutek nadmiernego hałasu wywoływanego przez studentów oczekujących na zajęcia lub odwiedzających pracowników często poza godzinami ich konsultacji. Pokoje są najczęściej również jedynym miejscem spotkań z innymi pracownikami naukowymi, co z uwagi na to, że są to zazwyczaj pomieszczenia kilkuosobowe, dodatkowo pogarsza warunki pracy. 
246 Kreowanie atrakcyjnych przestrzeni w miejscu pracy...

Wykres 2. Cechy używane przez respondentów do scharakteryzowania wyglądu zewnętrznego i wewnętrznego Wydziału

wygląd zewnętrzny wygląd wewnętrzny

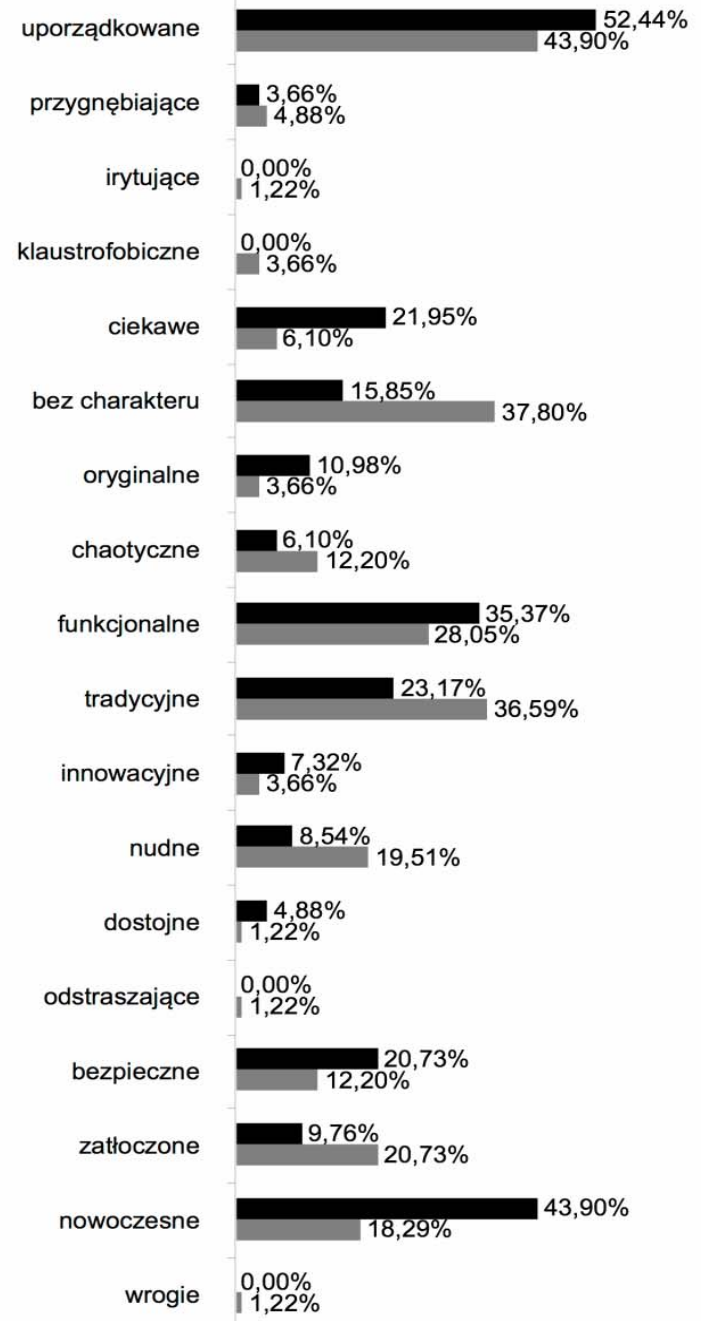

Źródło: Opracowanie własne na podstawie badania ankietowego.

$\mathrm{Z}$ innego punktu widzenia, istotnym dla użytkowania miejsca zagadnieniem jest sposób zorganizowania przestrzeni. Poddając ocenie to zagadnienie, także posłużono się pytaniem z kafeterią odpowiedzi, na którą składało się również osiemnaście cech. Rozmieszczenie pomieszczeń na WE-S UŁ oceniono przede wszystkim jako „skomplikowane” (40,2\%) i „,haotyczne” (26,83\%). Skompli- 
kowane rozmieszczenie pomieszczeń utrudnia przemieszczanie się $42,7 \%$ badanym. Oczywiście odnajdujemy także odpowiedzi wskazujące, że pracownicy przywykli do tego układu i w $51,2 \%$ przypadków organizacja przestrzeni nie sprawia im kłopotu. Trudności w tym zakresie ujawniają się jednak najczęściej, gdy oceny takiej dokonano w kontekście możliwości organizowania spotkań i łatwości przyjmowania gości spoza wydziału. W takim przypadku, w ocenie ankietowanych, aż $46,4 \%$ odwiedzającym trudno poruszać się po budynkach WE-S. W odniesieniu można ponownie posłużyć się tutaj słowami Ch. Aleksandra „Kiedy ktoś (...) wchodzi do grupy połączonych domów, zachodzi duże prawdopodobieństwo, że poczuje się zagubiony, o ile cały zbiór nie zostanie przed nim rozwinięty, tak by od razu mógł zobaczyć wejście do tego miejsca do którego zmierza" ${ }^{\prime 10}$. Jest to ważne nie tylko z perspektywy łatwości docierania do celu, czy oceny ergonomiczności obiektu, ponieważ „Ruch między pomieszczeniami jest równie ważny jak same pomieszczenia, a jego organizacja wywiera równie silny wpływ na interakcje społeczne w pomieszczeniach, jak same wnętrza tych pomieszczeń"11.

Ocena wygody użytkowania przestrzeni pracy wiąże się także z dostępnością i jakością punktów sanitarnych oraz pomieszczeń gastronomicznych. W przypadku węzłów sanitarnych można mówić o ich wzorcowym rozlokowaniu, ponieważ dostępność w tym zakresie na poziomie „dobrym” i „bardzo dobrym" określa zdecydowana większość pracowników (odpowiednio 45,12\% oraz $47,56 \%$ ). Natomiast dostępność i rozmieszczenie pomieszczeń gastronomicznych oceniana została zdecydowanie negatywnie przez $51,2 \%$ respondentów ${ }^{12}$. W tym przypadku konsekwencje tego stanu rzeczy mają nie tylko wymiar oceny czysto funkcjonalnej, ale sytuacja ta negatywnie wpływa także na procesy socjalizacji i budowy kapitału społecznego, które to często związane są z infrastrukturą gastronomiczną.

\section{Przestrzeń publiczna a dyfuzja wiedzy cichej}

Niewątpliwie przestrzeń wydziału powinna korzystnie wpływać na zawiązywanie i utrzymywanie kontaktów między pracownikami, jednak zdaniem aż $51,2 \%$ badanych tak nie jest. Dotyczy to zarówno przestrzeni wewnątrz budynków wydziału, jak i przestrzeni otwartych. W opinii respondentów przestrzeń otaczająca wydział nie sprzyja lub jest obojętna dla pracy naukowej, jest to

${ }^{10}$ Ch. Alexander, Język Wzorców. Miasta, budynki, konstrukcja, Gdańskie Wydawnictwo Psychologiczne, Sopot 2008, s. 638.

${ }^{11} \mathrm{Ch}$. Alexander, Język Wzorców. Miasta, budynki, konstrukcja, Gdańskie Wydawnictwo Psychologiczne, Sopot 2008, s. 507.

${ }^{12}$ W okresie realizacji badań na na WE-S UŁ funkcjonowała stołówka oraz dwa bufety (dostępność i rozmieszczenie automatów z napojami i przekąskami nie stanowiła przedmiotu badania). 
w znakomitej większości przestrzeń służąca transportowi. Skwery natomiast nie mają wystarczających cech, które determinowałyby ich wykorzystywanie przez pracowników $-85,4 \%$ badanych stwierdza, że w ogóle lub prawie w ogóle nie wykorzystuje przestrzeni zaaranżowanych wokół budynków wydziału, jako miejsc pracy lub miejsc budowania kapitału relacyjnego i wymiany wiedzy.

W tym kontekście istotne są również wskazania zgłaszane przez znaczną część respondentów $(63,4 \%)$, dotyczące braku centralnego miejsca spotkań lub innych przestrzeni „,wspólnych”, które byłyby dostępne jedynie dla pracowników. Miejsca takie stanowiłyby swego rodzaju infrastrukturę do budowania relacji, więzi społecznych, kapitału społecznego. Ponad 78\% respondentów deklaruje chęć wykorzystywania takich miejsc. W opinii respondentów budynki wydziału nie zapewniają warunków do organizowania spotkań z osobami spoza środowiska naukowego, co jest szczególnie istotne w kontekście budowania realizacji i współpracy nauki z biznesem czy innymi podmiotami publicznymi. Zdanie to podziela połowa badanych. Poznanie i zaufanie to niezbędne składniki do efektywnego funkcjonowania również tego typu organizacji, jaką jest uczelnia. Dowodzi tego przede wszystkim obecny sieciowy model realizacji procesów innowacyjnych. Respondenci podpowiadają także, jakie właściwości powinny mieć owe miejsca centralne, aby pełniły zakładane funkcje. Najczęściej wskazywanymi właściwościami takich miejsc były: wygodne miejsca do siedzenia (82,9\%), ekspres z kawą, herbatą (w minimalnej cenie) (72\%), dostęp do sieci Wi-Fi $72 \%$, ekran i multimedia do dyspozycji $57,3 \%$, codzienna prasa $46,3 \%$, bufet z drobnymi przekąskami 43,9\%, „enklawa zieleni” - kwiaty, dźwięki natury $32,9 \%$.

Obecnie, w znakomitej większości, regularne kontakty między naukowcami na wydziale istnieją jedynie na poziomie katedr i zakładów. Sprzyjają temu, określone jako dobre warunki biurowe, oceniane z perspektywy liczby osób pracujących w jednym pokoju. Ankietowani wskazują, że liczba osób przypadająca na pokój, w którym na co dzień pracują, jest odpowiednia - zgadza się z tym stwierdzeniem $72 \%$ badanych. W opinii respondentów na WE-S UŁ rozmieszczenie pracowników w pokojach, jest „optymalne” i gwarantuje, że pracownicy nie czują się od siebie odizolowani. Poczucie izolacji i separacji w pracy doskwiera bowiem jedynie 13,4\% osób. Co więcej, jeśli takie poczucie badani sygnalizują, częściej uzależniają je od organizacji pracy i stosunków między pracownikami $(53,7 \%)$, niż od właściwości technicznych biur i budynków $(32,5 \%)$ lub innych czynników $(24,4 \%)$.

Natomiast niekorzystna ocena w tym zakresie dotyczy możliwości organizacji pracy w zespołach i grupach zadaniowych. Ocena podstawowej infrastruktury, która w tym celu jest wykorzystywana - odpowiedniej przestrzeni biurowej jest niezadowalająca. Respondenci zapytani o to, czy mają łatwy dostęp do miejsc na wydziale, gdzie można zorganizować pracę w kilkunastoosobowej 
grupie projektowej, odpowiadaja co prawda niejednoznacznie: „raczej tak” $35,4 \%$ oraz „raczej nie” - 31,7\%, co jednak w kontekście wyników pracy i niskich wymagań sprzętowych (praktycznie braku potrzeb wykorzystywania kosztownej infrastruktury laboratoryjnej), należy ocenić negatywnie. Ze względu na lokalizację WE-S, poza tzw. kampusem UŁ, utrudniona jest także współpraca międzywydziałowa (istotna $\mathrm{w}$ kontekście projektów interdyscyplinarnych) $50 \%$ badanych przyznaje, że nie utrzymuje relacji z naukowcami z innych wydziałów UŁ. Jest to szczególnie zastanawiające z punktu widzenia istnienia Wydziału Zarządzania UŁ, gdzie funkcjonuje wielu naukowców zajmujących się podobną problematyka, do tej podejmowaną przez pracowników W-ES, tj. rachunkowościa, gospodarką przestrzenną, logistyką. Podobnie można by wymienić inne wydziały, których wiedza z pewnością ma charakter komplementarny: Wydział Prawa i Administracji, Wydział Nauk o Wychowaniu, Wydział Nauk Geograficznych, itd.

\section{Afirmacja przestrzeni pracy}

Techniczno-przestrzenne warunki pracy oraz poziom ich akceptacji przez naukowca wpływają na efektywność jego pracy, innowacyjność i zdolności twórcze. Celowe było zatem zebranie opinii na temat miejsc, gdzie najczęściej pracownicy badanego wydziału prowadzą prace badawcze i koncepcyjne, czyli pokoi w których „urzędują". Oceniano w tym przypadku na wstępie elementy aranżacji i wyposażenia pomieszczeń w kontekście potrzeb i preferencji użytkowników.

Jak dowodzą wyniki badań, realizowanych w sektorze prywatnym (m.in. badań wskazanych wyżej), samopoczucie użytkowników, a tym samym ich skłonność do pracy, jest silnie uzależniona od aranżacji wnętrza, a w szczególności od kolorów ścian. W związku z tym zapytano respondentów jak scharakteryzowaliby kolorystykę swoich pokoi - „mdła”, „drażniąca”, „neutralna”, „pozytywna”, „inspirująca”. Większość wybrała odpowiedzi: „neutralna” $(45,1 \%)$ i „pozytywna” (30,5\%). Kolejne pytania dotyczyły takich zagadnień wpływających na komfort pracy jak: oświetlenie, temperatura i hałas. I tak, zdecydowana większość ankietowanych jest zdania, że w swoich pokojach mają wystarczający dostęp do światła dziennego („raczej tak” - 26,83\% oraz „tak”-63,41\%). Nieco gorzej, ale wciąż relatywnie dobrze, jest $\mathrm{z}$ odpowiednim poziomem temperatury zarówno latem, jak i zimą (,raczej tak” - 24,39\% oraz „tak” - 41,46\%). Wydawało by się, że ze względu na lokalizację w śródmieściu Łodzi, a także liczne grupy studentów obecne na korytarzach wydziału, pracownikom doskwierać będzie hałas. Tymczasem aż $61 \%$ badanych uważa, że hałas im nie przeszkadza, bądź raczej nie przeszkadza. Jeśli już jednak hałas jest uciążliwy dla pracowników, to sytuacja ta wynika głównie z gwaru rozmów studenckich na korytarzach 
w bezpośrednim sąsiedztwie pokojów. Klimat pracy w biurze tworzy także okno, a w zasadzie to, co jest dzięki niemu widoczne: architektoniczna tkanka miasta i aktywność innych ludzi. Ocena tego elementu jest znacznie niższa, ponieważ aż 45,1\% pracowników podkreśla, że bezpośredni widok z okien w pokojach gdzie pracują trudno uznać za inspirujący. O ile takie parametry jak nasłonecznienie, hałas, czy temperatura, a także widok z okna, wymagają dość długiego czasu do wprowadzenia zmian, o tyle stosunkowo szybko na preferencje pracowników reagować można poprzez odpowiednie wyposażenie. Jak zatem oceniany jest stan wyposażenia i dostępu do infrastruktury biurowej? Respondenci pozytywnie odnoszą się do dostępności infrastruktury biurowej i uważają ją za zapewnioną na właściwym poziomie (,raczej tak" - 36,59\% oraz „tak” - 29,27\%). Co więcej, zazwyczaj oceniają meble biurowe, z których korzystają, jako funkcjonalne (,raczej tak” - 46,34\% oraz „tak”-31,71\%). Także jakość materiałów użytych do wykończenia pomieszczeń jest oceniana „dobrze” (25,61\%) lub „raczej dobrze” (52,44\%). Większość badanych $(68,3 \%)$ jest także zadowolona z powierzchni, jaką zajmują pokoje, oceniając że jest wystarczająca aby zapewnić poczucie komfortu podczas pracy. Wszystko to sprawia, że pokoje biurowe są odbierane przez większość pracowników jako wygodne i zaprojektowane ergonomicznie (,raczej tak”-35,37\% oraz „tak”-21,95\%). Dlatego też respondenci potwierdzają w większości, że lubią pracować w swoich pokojach („raczej tak” $-36,59 \%$ oraz „tak” - 32,93\%) oraz 54,9\% stwierdza także, że miejsce to sprzyja pracy naukowej.

Należy jednak zauważyć, że istnieje mimo wszystko znaczna grupa osób, która ma odmienne zdanie, co zdecydowanie należy uznać za wyzwanie z perspektywy pracodawcy. Uogólniając bowiem, istnieje grupa ponad $30 \%$ badanych, którzy stwierdzają, że nie lubią pracować przebywając na wydziale, a ponad $45 \%$ wskazuje, że nie jest to miejsce sprzyjające pracy naukowej. Można zatem zaryzykować wniosek, iż przebywanie znacznej części naukowców na wydziale jest mało efektywne z perspektywy pracy naukowej, nawet mimo względnie dobrych not, w zakresie oceny jakości tej przestrzeni wśród znacznej części respondentów. Pomijając jednak motywy nie związane $\mathrm{z}$ otoczeniem pracy, które mogą być przyczyną takiego stanu rzeczy, zapytano respondentów: co można byłoby zmienić w przestrzeni wydziału, aby determinowała ona naukowców do bardziej twórczej pracy? W odpowiedziach, po pierwsze ujawnia się swego rodzaju konflikt między pracownikami a studentami, a więc dwoma grupami, które jednocześnie użytkują tę samą przestrzeń. Respondenci wyrażają chęć przestrzennego rozdzielenia sfery dydaktycznej od naukowej, ponieważ studenci zbyt często odwiedzają ich poza godzinami konsultacji (teoretycznie dedykowanymi pracy naukowej). Warto tu przytoczyć dwie wypowiedzi badanych: ${ }^{13}$

${ }^{13}$ Zachowana pisownia oryginalna. Źródło: na podstawie badania ankietowego. 
- „(..) niestety nie umiem pracować naukowo na wydziale, wszystko mnie rozprasza - cały czas ktoś wchodzi do pokoju, zachęca do rozmowy. Potrzebowałabym ciszy i spokoju, abym mogła się skupić. Tak naprawdę pracuję w domu (...)";

- „rozdzielenie miejsca kontaktu ze studentami (konsultacji) od miejsca pracy naukowej".

Istotny zdaje się również brak centralnego miejsca spotkań, które dostępne byłoby jedynie dla pracowników. Okazuje się, że odpowiednik pokoju nauczycielskiego, znanego ze szkół podstawowych i średnich, wydaje się być elementem pożądanym przez społeczność akademicką ${ }^{14}$ :

- „Zważywszy ograniczenia architektoniczne, to co wydaje się możliwe do zrobienia, to zorganizowanie klubu pracowniczego jako miejsca spotkań (...)";

- „Brakuje patio, jak jest w większości wydziałów. Brak konkretnego, centralnego przestrzennego miejsca, w którym wszyscy mogliby się spotykać na przerwie np. poczytać prasę codzienną, wypić kawę, podyskutować itp.".

Po drugie dość często pojawiały się sugestie dotyczące sfery organizacyjnej, takie jak na przykład postulaty dotyczące zapewnienia pracownikom samodzielnych pokoi biurowych, wydłużenia godzin funkcjonowania wydziału po to, by móc pracować $\mathrm{w}$ pokojach $\mathrm{w}$ godzinach wieczornych i nocnych, zgodnie $\mathrm{z}$ indywidualną preferencją trybu pracy.

\section{Podsumowanie}

Podsumowując wyniki, można sformułować następujący wniosek o charakterze ogólnym dotyczący zrealizowanych badań: przestrzeń pracy, aktualnie zdefiniowana w WE-S, ma charakter przestrzeni biurowo-dydaktycznej, co oznacza, że pracownicy naukowi w sposób skuteczny mogą realizować cele związane z procesem dydaktycznym (ewentualnie realizują obowiązki o charakterze administracyjnym), jednak ich druga podstawowa działalność zawodowa praca naukowa - wykonywana jest najczęściej poza wydziałem. Znaczna część respondentów wyraża pozytywną opinię na temat warunków sprzyjających pracy naukowej w przestrzeni WE-S, jednak tylko $20 \%$ czasu spędzanego w murach uczelni badani poświęcają na pracę naukową. Jaka może być tego przyczyna? Na podstawie uzyskanych wyników badań trudno dokładnie wnioskować, jaki odsetek pracowników determinowany jest do takiego wyboru za sprawą czynników $\mathrm{w}$ istocie związanych $\mathrm{z}$ komfortem pracy i jakością otoczenia/przestrzeni pracy. Podsumowując uzyskane wyniki można szacować, że

\footnotetext{
${ }^{14}$ Zachowana pisownia oryginalna. Źródło: na podstawie badania ankietowego.
} 
obecnie ok. 25-35\% respondentów negatywnie identyfikuje warunki związane z oceną przestrzeni pracy na WE-S, co jest bezpośrednim wyzwaniem dla pracodawcy. Wyniki badań sugerują jednak, że istnieją silne motywy nie związane z tymi elementami, które powodują że pracownicy naukowi rzadko pracują naukowo przebywając na wydziale. Oczywiście wyniki badań nie pozwalają wnioskować jakie czynniki są za to głównie odpowiedzialne, można jedynie domniemywać, że mogą być to motywy związane na przykład z: miejscem zamieszkania pracowników znacznie oddalonym od miejsca pracy, kulturą organizacyjną w miejscu pracy, ilością obowiązków dydaktyczno-administracyjnych wypełniających znaczną część dnia pracy, czy może niską skłonnością i zainteresowaniem pracowników pracą naukową. Tym niemniej sytuacja ta znacząco wpływa na zmniejszenie produktywności kapitału ludzkiego i wiedzy w instytucji powołanej by wiedze produkować i uczestniczyć w procesach jej dyfuzji. Pomijając $\mathrm{w}$ ocenie istniejące kontakty nieformalne, i działania indywidualne naukowców, można sformułować wniosek o niskiej efektywności instytucjonalnej w tym zakresie.

Należy podkreślić, iż realizacja tak zoperacjonalizowanego projektu badawczego, pozwala formułować postulaty dotyczące konkretnych działań, na rzecz zwiększenia efektywności wykorzystania kapitału klasy kreatywnej w badanym obszarze. Propozycje te mogą mieć tym bardziej wymierny charakter, gdyż dotyczą środowiska jasno zdefiniowanego pod względem: właściwości, rozmiarów, potrzeb, obszarów działalności, itp., oraz precyzyjnie zlokalizowanego w przestrzeni. Zrealizowane badania oczywiście nie wyczerpują potrzeb w zakresie identyfikacji przedmiotu, jednak stanowią same w sobie postulat, dotyczący konieczności stosowania bardziej kompleksowych rozwiązań związanych z inwestowaniem w kapitał ludzki, szczególnie odpowiadający za produkowanie wiedzy innowacyjnej. Projekty inwestycyjne nie powinny kończyć się jedynie na warstwie infrastrukturalnej: powinny odpowiadać na oczekiwania ludzi, którzy w oparciu o tę infrastrukturę będą realizować cele, do których zostali powołani celami organizacji. W tym przypadku nie chodzi jedynie o standardowo określoną jakość otoczenia pracy, a tworzenie takich warunków pracy (infrastrukturalnych, organizacyjnych, estetycznych, społecznych, itd.), które będą zachęcać swoimi właściwościami pracownika do pracy twórczej, jednocześnie „wabiąc" go do tej przestrzeni.

\section{Bibliografia}

Regionalny wymiar polityki rozwoju kapitalu ludzkiego. Przyklad Włoch, Wielkiej Brytanii, Niemiec i Polski, Przygodzki Z. (red.), Wydawnictwo Difin, Warszawa 2013.

Neufert E., Podręczniki projektowania architektoniczno-budowlanego, Wydawnictwo Arkady, Warszawa 2008. 
Nowakowska A., Regionalny wymiar procesów innowacji, Wydawnictwo Uniwersytetu Łódzkiego, Łódź 2011.

Nowakowska A., Przygodzki Z., Sokołowicz M., Region w gospodarce opartej na wiedzy. Kapitat ludzki, innowacje, korporacje transnarodowe, Wydawnictwo Difin, Warszawa 2011.

Alexander Ch., Język Wzorców. Miasta, budynki, konstrukcja, Gdańskie Wydawnictwo Psychologiczne, Sopot 2008.

Gehl J., Życie między budynkami. Użytkowanie przestrzeni publicznych, Wydawnictwo RAM, Kraków 2009. 